Article

\title{
Four In Silico Designed and Validated qPCR Assays to Detect and Discriminate Tilletia indica and T. walkeri, Individually or as a Complex
}

\author{
Émilie D. Tremblay ${ }^{1, *} \mathbb{1}$, Julie Carey ${ }^{1}$, Guillaume J. Bilodeau ${ }^{2}\left(\mathbb{D}\right.$ and Sarah Hambleton ${ }^{1, *}$ \\ 1 Agriculture and Agri-Food Canada (AAFC), 960 Carling Avenue, Ottawa, ON K1A 0C6, Canada; \\ Julie.Carey@agr.gc.ca \\ 2 Canadian Food Inspection Agency (CFIA), 3851 Fallowfield Road, Ottawa, ON K2H 8P9, Canada; \\ Guillaume.Bilodeau@inspection.gc.ca \\ * Correspondence: Emilie.Tremblay@agr.gc.ca (É.D.T.); Sarah.Hambleton@agr.gc.ca (S.H.); \\ Tel.: +1-613-759-1728 (É.D.T.); +1-613-759-1769 (S.H.)
}

check for

updates

Citation: Tremblay, É.D.; Carey, J.; Bilodeau, G.J.; Hambleton, S. Four In Silico Designed and Validated qPCR Assays to Detect and Discriminate Tilletia indica and T. walkeri, Individually or as a Complex. Biology 2021, 10, 1295. https:// doi.org/10.3390/biology10121295

Academic Editor: Luigi De Bellis

Received: 9 November 2021 Accepted: 1 December 2021 Published: 8 December 2021

Publisher's Note: MDPI stays neutral with regard to jurisdictional claims in published maps and institutional affiliations.

Copyright: $\odot 2021$ by Her Majesty the Queen in Right of Canada, as represented by the Minister of Agriculture and Agri-Food Canada. Submitted for possible open access publication under the terms and conditions of the Creative Commons Attribution (CC BY) license. (https://creativecommons.org/licenses/by/4.0/).
Simple Summary: Plant pathogens represent a constant threat to human and animal food, as well as the economy. International trading is constantly expanding and has been known as a means of transportation and introduction for plant pests (e.g., bacteria, viruses, fungi, and insects) in new areas. They can damage or completely ruin a harvest and there are often strict regulations for the most unwanted plant pests in order to keep their incidence confined. The fungal plant pathogen Tilletia indica causes Karnal bunt, a wheat disease that breaks or hollows grains, grows in dark powdery masses, and emits a foul fishy odor, and is therefore highly regulated by a number of country authorities, many of which respond by imposing quarantine regulations. While there are many diagnostic methods developed (microscopy, molecular assays, etc.) to identify Karnal bunt, they have limitations. This study presents four highly sensitive quantitative PCR assays with molecular probes targeting unknown genomic regions for the detection and identification of T. indica and T. walkeri-its closest relative-and the species-complex including both species. Bioinformatics analyses of DNA sequences were used to design the toolkit presented.

Abstract: Several fungi classified in the genus Tilletia are well-known to infect grass species including wheat (Triticum). Tilletia indica is a highly unwanted wheat pathogen causing Karnal bunt, subject to quarantine regulations in many countries. Historically, suspected Karnal bunt infections were identified by morphology, a labour-intensive process to rule out other tuberculate-spored species that may be found as contaminants in grain shipments, and the closely-related pathogen T. walkeri on ryegrass (Lolium). Molecular biology advances have brought numerous detection tools to discriminate Tilletia congeners (PCR, qPCR, etc.). While those tests may help to identify T. indica more rapidly, they share weaknesses of targeting insufficiently variable markers or lacking sensitivity in a zero-tolerance context. A recent approach used comparative genomics to identify unique regions within target species, and qPCR assays were designed in silico. This study validated four qPCR tests based on single-copy genomic regions and with highly sensitive limits of detection ( $200 \mathrm{fg})$, two to detect T. indica and T. walkeri separately, and two newly designed, targeting both species as a complex. The assays were challenged with reference DNA of the targets, their close relatives, other crop pathogens, the wheat host, and environmental specimens, ensuring a high level of specificity for accurate discrimination.

Keywords: wheat; ryegrass; Karnal bunt; dwarf bunt; phytopathogen; qPCR 


\section{Introduction}

Tilletia indica Mitra [1], the causal agent of Karnal bunt on wheat (Triticum aestivum and T. durum) and triticale ( $\times$ Triticosecale) is considered a serious threat to crop production in many regions [2,3]. The fungal disease was initially found in Karnal, India, in 1931, and currently occurs mainly in Asian countries such as India, Afghanistan, Iran, Iraq, Pakistan, and Nepal [1,4-7]. The first detection in North America was in 1972 in Mexico, and it has since been reported in Brazil, South Africa, and USA [4,5,8-12]. Some authors claim that the importance drawn to it is overrated given its limited distribution [13,14], yet many countries (Canada, USA, Mexico, New Zealand, Morocco, Israel, Belarus, Norway, and other European countries) continue to impose quarantine pest regulations on wheat imports and exports $[4,5]$ to prevent further spread. The pathogen can be dispersed quickly and is challenging to eradicate once its spores are present in soil, where they can survive for up to five years $[5,9,15,16]$. The spread of Karnal bunt spores is likely to cause infection, which can dramatically hamper a harvest and reduce production due to kernel bunting, and the foul smell and taste associated with the infection renders wheat and wheat-products such as flour unfit for consumption [4,17-21].

The detection of Karnal bunt in the USA in 1996 quickly escalated into an embargo on shipments because of the scale of this country's wheat-exports [22,23]. Many American and European countries free from Karnal bunt established a ban on imports of wheat, triticale, and other susceptible crops from affected countries or imposed mandatory phytosanitary certification for imported grain to be free from $T$. indica and to originate from pest-free states or areas $[24,25]$. The USA also went through a country-wide quarantine survey program to screen for and contain outbreaks in affected areas [26]. Although it is reported that seed-borne diseases can be controlled using fungicides or chemical treatments, there is also a recent upsurge in those diseases due to biological agriculture practices [27-29]. In addition, it is known that climate change could enhance the emergence of plant pathogens such as Karnal bunt given the occurrence of proper temperature and moisture conditions newly met by certain wheat growing areas [30-33].

It is essential to have the resources to differentiate $T$. indica from morphologically and genetically similar species given the social, economical, and environmental impacts at stake [34]. Rapid and sensitive tools to detect and identify Tilletia species are required for Karnal bunt management and forecasting, especially for the leading countries of wheat exports which, in 2018, were Russia (US $\$ 8.4$ billion/year), Canada (US $\$ 5.7$ billion/year), and USA (US $\$ 5.4$ billion/year) [35]. Although there are over a hundred Tilletia species, most do not infect wheat and have little to no impact for crop production. Amongst the species closely-related to T. indica, the ryegrass pathogen T. walkeri Castlebury and Carris [23], as yet reported only from Australia, China, New Zealand and USA [36], is of concern as a grain contaminant. The species has received the attention of numerous scientists attempting to decipher minor, yet critical morphological or molecular differences between the two congeners $[4,12-14,22,23,37-40]$. Ryegrass is also commonly cultivated in wheat-growing regions, increasing the risk of mixtures in seed lots [23,41].

Several molecular assays allowing researchers to discriminate or detect selected Tilletia spp. are already available (Table 1), although many of them have limitations. For instance, as previously reported [42-44], the Internal Transcribed Spacer (ITS) region is a marker with limited variation between $T$. indica and its closest relative, T. walkeri. This region has been exploited by approaches such as Random Amplified Polymorphic DNA (RAPD) combined with Polymerase Chain Reaction (PCR) and Restriction Fragment Length Polymorphism (RFLP) [45], PCRs or PCR-combined methods [44,46-48], RFLP [42], and real-time PCR (qPCR) [49-51]. There are only two consistent single nucleotide polymorphisms (SNPs) between the publicly available ITS sequences of the two species [42-44]. All but one of the diagnostic assays sanctioned by the International Plant Protection Convention (ISPM 27) [52] for T. indica diagnostics are based on ITS [44,45,49], while the assay by Frederick et al. [37] targets mitochondrial DNA. 
Table 1. Chronological summary of assays developed to detect or discriminate Tilletia species.

\begin{tabular}{|c|c|c|c|}
\hline Year & Type of Assay & Purpose of Assay & References \\
\hline \multicolumn{4}{|c|}{ Targeting ITS ${ }^{a}$ region } \\
\hline 1998 & $\mathrm{RAPD}^{\mathrm{b}}+\mathrm{PCR}^{\mathrm{c}}+\mathrm{RFLP}^{\mathrm{d}}$ & Discriminate T. indica from other Tilletia species & [45] \\
\hline 2000 & REP ${ }^{e}-P C R$ genomic fingerprinting & $\begin{array}{l}\text { Separate species from the } T \text {. indica } / T \text {. walkeri } \\
\text { complex from those of the } T \text {. controversa complex }\end{array}$ & [47] \\
\hline 2001 & RFLP & Discriminate T. indica from T. walkeri & [42] \\
\hline 2006 & 2 step PCR + FRET $g$ & Discriminate T. indica from T. walkeri & [44] \\
\hline 2006 & PCR + dot blot & Discriminate T. caries, $T$. foetida and T. controversa & [48] \\
\hline 2009 & 5-plex qPCR ${ }^{h}$ & $\begin{array}{l}\text { Discriminate T. indica, T. walkeri, T. horrida, T. ehrhartae } \\
\text { and the T. controversa (broad range) complex }\end{array}$ & [49] \\
\hline 2011 & PCR & Discriminate $T$. indica from $T$. horrida and T. caries & [46] \\
\hline 2017 & qPCR & Detect spores of T. indica in soil & [51] \\
\hline 2019 & 5-plex qPCR & Validation of Tan et al. 2009 qPCR assays & [50] \\
\hline \multicolumn{4}{|c|}{ Targeting Mitochondrial DNA } \\
\hline 1996 & PCR & Discriminate T. indica from other smut fungi & [53] \\
\hline 1996 & PCR & Discriminate $T$. indica from other Tilletia species & [54] \\
\hline 2000 & qPCR & $\begin{array}{l}\text { One primer set to detect } T \text {. indica, } \\
\text { one primer set to detect } T \text {. walkeri }\end{array}$ & [37] \\
\hline 2011 & PCR & Discriminate T. indica from T. horrida & [46] \\
\hline 2016 & LAMP $^{\mathrm{i}}$ & Discriminate $T$. indica from other closely-related species & [55] \\
\hline 2016 & LAMP & Discriminate $T$. indica from other closely-related species & [16] \\
\hline \multicolumn{4}{|c|}{ Targeting unknown region } \\
\hline 2002 & RAPD-PCR & Discriminate T. indica and T. barclayana & [56] \\
\hline
\end{tabular}

${ }^{a}$ Internal Transcribed Spacer. Assays may target the whole region or solely part of it; ${ }^{\mathrm{b}}$ Random Amplified Polymorphic DNA; ${ }^{\mathrm{c}}$ Polymerase Chain Reaction; ${ }^{\mathrm{d}}$ Restriction Fragment Length Polymorphism; ${ }^{\mathrm{e}}$ Repetitive-Sequence-Based; ${ }^{\mathrm{f}}$ Stated in the publication as including Tilletia caries, T. laevis, T. contraversa, T. fusca, T. bromi and T. goloskokovi; ${ }^{g}$ Fluorescence Resonance Energy Transfer; ${ }^{\text {h }}$ Quantitative Polymerase Chain Reaction; ${ }^{\mathrm{i}}$ Loop-Mediated Isothermal Amplification.

Recognized in the scientific community studying Tilletia spp., the ITS-related limitation was addressed by scientists who thereafter focused on alternate regions such as mitochondrial DNA. While PCR assays were designed to differentiate the causal agent of Karnal bunt from other smut fungi or Tilletia species [46,53,54], a qPCR assay was developed to distinguish T. indica and T. walkeri [37]. Two Loop-mediated isothermal Amplification (LAMP) assays were also designed to differentiate T. indica from other close relatives [16,55]. However, Tan et al. [16] reported that the LAMP assay by Gao et al. [55] had specificity issues with some T. indica isolates. An assay was also designed in an unknown region by Mishra et al. [56]. One limitation shared by all of those non-ITS targeting assays is their level of sensitivity, which is critical in an absolute absence requirement context such as for Karnal bunt. The qPCR assay of Frederick et al. [37] could detect 5 pg of DNA, making it twice as sensitive as the LAMP assays of Gao et al. [55] at $\geq 10 \mathrm{pg}$ of DNA or Tan et al. [16] at $10 \mathrm{pg}$ of fungal DNA. Plus, although the assay by Ferreira et al. [54] is more sensitive (1 pg), it cannot discriminate T. walkeri.

Other limitations include the inability to detect more than one species simultaneously or a requirement for teliospore germination prior to molecular analysis, which slows the diagnostic process. Several previously developed assays $[42,53,56]$ face one or both, rendering them fairly low-throughput. The international protocols for the diagnostic of $T$. indica involve morphological observations, isolation, and germination of single spores [52], which are time-consuming and require highly-trained personnel, in addition to molecular assays targeting the ITS region [44,45,49] or mitochondrial DNA [37]. Similarly, approaches like size-selective sieving of teliospores, a modified version of the general seed-wash centrifuge method, can be limited by the low number of spores present or the low germination frequency related to dormancy $[15,50,57,58]$.

Different approaches have recently been taken to attempt a better differentiation method for T. indica and its close relatives. For instance, Sharma et al. [59] screened for simple sequence repeats, or microsatellites, for diagnostics and genetic diversity studies of 
smut and bunt fungi and they included cross-transferable markers for T. indica. Promisingly, the project appears to be the first one to develop microsatellites for identification and validation of T. indica. Given sufficient levels of polymorphism across genera, the tool has great potential to evaluate genetic variation, but it requires further testing for a more comprehensive validation. Nguyen et al. [43] took a comparative genomics bioinformatics approach to screen for signature, unique, and single-copy regions theoretically variable enough to differentiate all the unwanted wheat-infecting Tilletia species; i.e., T. caries, T. controversa, and T. laevis as well as T. indica. Although their methods identified candidate regions, their High-Throughput/WGS protocol was only tested in silico.

The objective of this study was to perform wet-laboratory validation and optimization of the T. indica and T. walkeri candidate assays from Nguyen et al. [43] and design additional new assays for detecting both species at once. Extensive testing was performed using reference materials and environmental specimens to assess specificity and sensitivity. The result is an array of four qPCR assays that can determine whether samples-e.g., fieldcollected specimens, pure cultures, or seed lots-comprise entities from the T. indica/ T. walkeri complex and if so, identify whether either or both are present, at a highly sensitive detection level.

\section{Materials and Methods}

\subsection{Fungal Material and DNA Extraction}

Forty-eight pure culture isolates representing 11 Tilletia species were obtained to serve as reference material for this study (Table 2), including 20 for T. indica and 3 for T. walkeri, the 2 target species. The Canadian Collection of Fungal Cultures, Ottawa, Canada (DAOMC) strains were cultured as polysporidial isolates from surface-sterilized germinated teliospores by the Canadian Food Inspection Agency (CFIA) and most were included in a study by McDonald et al. [47]. They were later provided to Agriculture and Agri-Food Canada (AAFC) as pure cultures for research purposes and for long term preservation in DAOMC. The rest were obtained from the American Type Culture Collection (ATCC; Manassas, VA, USA) or the CBS-KNAW Filamentous Fungi Collection (CBS, Westerdijk Fungal Biodiversity Institute, Utrecht, Netherlands). DNA was extracted from cultures grown on solid potato dextrose agar (Difco, Becton Dickinson, Franklin Lakes, NJ, USA) at room temperature in the dark and using one of the following kits with the manufacturer's instructions: CTAB (https: / / www.protocols.io/view / fungal-ctab-dna-extraction-bhx8j 7rw, accessed on 8 November 2021), DNeasy Plant Mini kit (QI, Toronto, ON, Canada), E.Z.N.A. ${ }^{\circledR}$ Fungal DNA Miniprep kit (VWR, Mississauga, ON, Canada), Macherey-Nagel Nucleospin ${ }^{\circledR} 96$ Plant or Macherey-Nagel NucleoMag ${ }^{\circledR} 96$ Trace kit (Macherey Nagel GmbH \& Co. KG, Düren, Germany), OmniPrep ${ }^{\mathrm{TM}}$ for Fungi kit (G-Biosciences, St. Louis, MO, USA), or UltraClean ${ }^{\mathrm{TM}}$ Microbial DNA Isolation Kit (MO BIO Laboratories Inc., Carlsbad, CA, USA). 
Table 2. Voucher numbers, host genus, provenance, year collected, ITS GenBank accession numbers and assay validation results for the reference Tilletia strains used in this study.

\begin{tabular}{|c|c|c|c|c|c|c|c|c|c|}
\hline \multirow[b]{2}{*}{ Species } & \multirow[b]{2}{*}{ Voucher No. ${ }^{a}$} & \multirow[b]{2}{*}{ Host Genus } & \multirow[b]{2}{*}{ Year Collected } & \multirow[b]{2}{*}{ Provenance } & \multirow[b]{2}{*}{$\begin{array}{l}\text { ITS GenBank } \\
\text { Accession No. }\end{array}$} & \multicolumn{4}{|c|}{ TaqMan qPCR Results } \\
\hline & & & & & & $\begin{array}{c}\text { TinOG09272 } \\
\text { T. indica }\end{array}$ & $\begin{array}{c}\text { TwaOG10415 } \\
\text { T. walkeri }\end{array}$ & $\begin{array}{c}\text { OG08220 } \\
\text { T. indica and T. walkeri }\end{array}$ & $\begin{array}{c}\text { OG01193 } \\
\text { T. indica and T. walkeri }\end{array}$ \\
\hline \multirow{18}{*}{ T. indica } & DAOMC 236406 & Triticum & 1996 & Mexico & OL653674 & + & - & + & + \\
\hline & DAOMC 236407 & Triticum & 1995 & India & OL653675 & + & - & + & + \\
\hline & DAOMC 236408 & Triticum & 1997 & India & OL653676 & + & - & + & + \\
\hline & DAOMC 236409 & Triticum & 1997 & India & HQ317520 & + & - & + & + \\
\hline & DAOMC 236410 & Triticum & 1997 & India & OL653677 & + & - & + & + \\
\hline & DAOMC 236411 & Triticum & 1997 & India & OL653678 & + & - & + & + \\
\hline & DAOMC 236412 & Triticum & 1985 & Mexico & OL653679 & + & - & + & + \\
\hline & DAOMC 236415 & Triticum & 1995 & India & OL653681 & + & - & + & + \\
\hline & DAOMC 236416 & Triticum & 1997 & Pakistan & OL653682 & + & - & + & + \\
\hline & DAOMC 236417 & Triticum & 1997 & Pakistan & OL653683 & + & - & + & + \\
\hline & DAOMC 236418 & Triticum & 1996 & Mexico & OL653684 & + & - & + & + \\
\hline & DAOMC 236419 & Triticum & 1997 & India & OL653685 & + & - & + & + \\
\hline & DAOMC 236420 & Triticum & 1997 & India & OL653686 & + & - & + & + \\
\hline & DAOMC 236421 & Triticum & 1997 & Pakistan & OL653687 & + & - & + & + \\
\hline & DAOMC 238027 & Triticum & not known & Mexico & HQ317519 & + & _- & + & + \\
\hline & DAOMC 238045 & Triticum & 1981 & Mexico & OL653699 & + & - & + & + \\
\hline & DAOMC 238046 & Triticum & 1991 & India & OL653700 & + & - & + & + \\
\hline & DAOMC 238047 & Triticum & 1995 & USA & HQ317581 & + & - & + & + \\
\hline \multirow{3}{*}{ T. walkeri } & DAOMC 236422 & Lolium & 1996 & USA & OL653688 & - & + & + & + \\
\hline & DAOMC 236423 & Lolium & 1996 & USA & OL653689 & _- & + & + & + \\
\hline & DAOMC 238049 & Lolium & 1998 & USA & OL653702 & - & + & + & + \\
\hline T. asperifolia & ATCC 90929 & Muhlenbergia & not known & USA & OL653714 & - & - & - & - \\
\hline T. brevifaciens & CBS 121948 & Thinopyrum & not known & Poland & OL653708 & - & - & - & - \\
\hline \multirow{7}{*}{ T. bromi } & CBS 123001 & Bromus & not known & USA & OL653706 & - & - & - & - \\
\hline & CBS 123002 & Bromus & not known & USA & OL653705 & - & - & - & - \\
\hline & ATCC 90927 & Bromus & not known & USA & OL653712 ${ }^{c}$ & - & - & _- & - \\
\hline & DAOMC 238034 & Bromus & 1991 & USA & OL653691 ${ }^{c}$ & - & - & - & _- \\
\hline & DAOMC 238035 & Bromus & 1995 & USA & OL653692 c & - & - & - & - \\
\hline & DAOMC 238036 & Bromus & 1991 & USA & OL653693 ${ }^{c}$ & - & - & - & - \\
\hline & ATCC 90928 & Bromus & not known & USA & OL653713 ${ }^{d}$ & - & - & - & - \\
\hline \multirow{3}{*}{ T. caries } & CBS 121951 & Triticum & not known & Sweden & OL653707 & - & - & - & - \\
\hline & DAOMC 238032 & Triticum & 1996 & USA & HQ317579 & - & - & - & - \\
\hline & DAOMC 238033 & Triticum & 1996 & USA & HQ317580 & - & - & - & - \\
\hline
\end{tabular}


Table 2. Cont.

\begin{tabular}{|c|c|c|c|c|c|c|c|c|c|}
\hline \multirow[b]{2}{*}{ Species } & \multirow[b]{2}{*}{ Voucher No. $^{a}$} & \multirow[b]{2}{*}{ Host Genus } & \multirow[b]{2}{*}{ Year Collected } & \multirow[b]{2}{*}{ Provenance } & \multirow[b]{2}{*}{$\begin{array}{l}\text { ITS GenBank } \\
\text { Accession No. }\end{array}$} & \multicolumn{4}{|c|}{ TaqMan qPCR Results } \\
\hline & & & & & & $\begin{array}{l}\text { TinOG09272 } \\
\text { T. indica }\end{array}$ & $\begin{array}{c}\text { TwaOG10415 } \\
\text { T. walkeri }\end{array}$ & $\begin{array}{c}\text { OG08220 } \\
\text { T. indica and T. walkeri }\end{array}$ & $\begin{array}{c}\text { OG01193 } \\
\text { T. indica and T. walkeri }\end{array}$ \\
\hline \multirow{2}{*}{ T. controversa } & ATCC 42079 & Triticum & not known & USA & OL653710 e & - & - & - & - \\
\hline & DAOMC 238052 & Triticum & 1997 & Canada & OL653703 e & - & - & - & - \\
\hline \multirow{5}{*}{ T. fusca } & ATCC 90926 & Vulpia & not known & USA & OL653711 & - & - & - & - \\
\hline & DAOMC 238041 & Vulpia & 1996 & USA & OL653696 & - & - & - & - \\
\hline & DAOMC 238042 & Vulpia & 1995 & USA & OL653697 & - & - & - & - \\
\hline & DAOMC 238043 & Vulpia & 1995 & USA & OL653698 & - & - & - & - \\
\hline & DAOMC 238053 & Vulpia & 1995 & USA & OL653704 & - & - & - & - \\
\hline T. goloskokovii & CBS 122995 & Apera & not known & USA & OL653709 & - & - & - & - \\
\hline \multirow{2}{*}{ T. horrida } & DAOMC $236425^{\mathrm{b}}$ & Oryza & 1997 & USA & HQ317521 & - & - & - & - \\
\hline & DAOMC $238029^{b}$ & Oryza & 1996 & USA & OL653690 & - & - & - & - \\
\hline \multirow{2}{*}{ T. laevis } & DAOMC 238039 & Triticum & 1997 & Australia & OL653694 & - & - & - & - \\
\hline & DAOMC 238040 & Triticum & 1997 & Australia & OL653695 & - & - & - & - \\
\hline
\end{tabular}

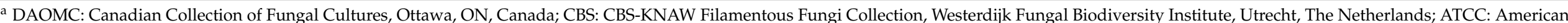

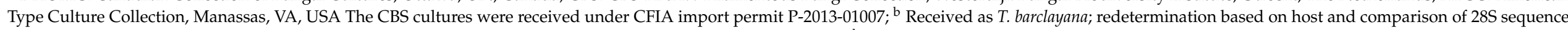

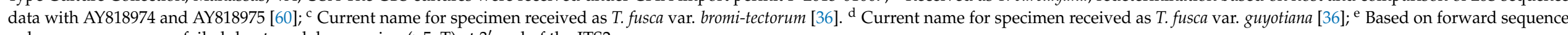
only; reverse sequence failed due to polybase region $(>5 \mathrm{xT})$ at $3^{\prime}$ end of the ITS2 spacer. 
Environmental specimens consisting of dried plant parts or seeds infected with various Tilletia species were obtained from collaborators at the United States Department of Agriculture (Table 3). For each specimen, teliospores from a single spore ball, or for T. pallida from multiple seeds, were sampled and DNA was extracted with the Nucleomag 96 Trace Kit on a Kingfisher $\mathrm{mL}$ automated system (ThermoFisher Scientific, Waltham, MA, USA), with the following customizations. Prior to extraction, samples were ground using liquid nitrogen and sterile disposable micro-centrifuge tube pestles (PES-15-B-SI, Axygen, Corning, NY, USA) or homogenized using a Bertin Precellys 24 tissue homogenizer instrument (Bertin Technologies SAS, Montigny-le-Bretonneux, France) set at $6000 \mathrm{rpm}$ for one cycle of $40 \mathrm{~s}$. Tubes containing samples and $200 \mu \mathrm{L}$ FLB were gently vortexed for $15 \mathrm{~s}$, spun at $1500 \times \mathrm{g}$ for $15 \mathrm{~s}$, incubated at $56{ }^{\circ} \mathrm{C}$ for $30 \mathrm{~min}$ (to ensure optimal lysis) while being mixed by flicking occasionally. Next, $30 \mu \mathrm{L}$ of RNase Cocktail Enzyme Mix (ThermoFisher Scientific) solution and $10 \mu \mathrm{L}$ of RNase A $(20 \mathrm{mg} / \mathrm{mL})$ (ThermoFisher Scientific) were added (to reduce the amount of RNA), and the incubation, vortexing, mixing steps repeated. Twenty-five microliters of the proteinase $\mathrm{K}$ solution were added to each sample, with vortexing and mixing repeated. Then, samples were incubated for $1 \mathrm{~h}$ at $56{ }^{\circ} \mathrm{C}$, centrifuged at $5600 \times g$ for 5 min and the supernatant of the lysed samples ( $\geq 225 \mu \mathrm{L}$ ) transferred to the Kingfisher $\mathrm{mL}$ machine for processing.

Table 3. Voucher numbers, provenance, year collected, ITS GenBank accession numbers and assay validation results for the field-collected environmental Tilletia specimens used in this study.

\begin{tabular}{|c|c|c|c|c|c|c|c|c|}
\hline \multirow[b]{2}{*}{ Name } & \multirow[b]{2}{*}{ Voucher No. ${ }^{a}$} & \multirow[b]{2}{*}{$\begin{array}{c}\text { Year } \\
\text { Collected }\end{array}$} & \multirow[b]{2}{*}{ Provenance } & \multirow[b]{2}{*}{$\begin{array}{l}\text { ITS GenBank } \\
\text { Accession No. }\end{array}$} & \multicolumn{4}{|c|}{ TaqMan qPCR Results } \\
\hline & & & & & $\begin{array}{l}\text { TinOG09272 } \\
\text { T. indica }\end{array}$ & $\begin{array}{l}\text { TwaOG10415 } \\
\text { T. walkeri }\end{array}$ & $\begin{array}{c}\text { OG08220 } \\
\text { T. indica and } \\
\text { T. walkeri }\end{array}$ & $\begin{array}{l}\text { OG01193 } \\
\text { T. indica and } \\
\text { T. walkeri }\end{array}$ \\
\hline \multirow{11}{*}{ T. indica } & KBW 005 & 1991 & India & OL636488 & + & - & + & + \\
\hline & KBW 011 & 1997 & India & OL636489 & + & - & + & + \\
\hline & KBW 012 & 1997 & India & OL636490 & + & - & + & + \\
\hline & KBW 017 & 1981 & Mexico & OL636491 & + & - & + & + \\
\hline & KBW 029 & 1991 & Mexico & OL636492 & + & - & + & + \\
\hline & KBW 038 & 1984 & USA & OL636493 & + & - & + & + \\
\hline & KBW 039 & 1985 & Pakistan & OL636498 & + & - & + & + \\
\hline & KBW 042 & 2000 & S. Africa & OL636494 & + & - & + & + \\
\hline & KBW 047 & 1995 & USA & OL636495 & + & - & + & + \\
\hline & KBW 050 & 1996 & USA & OL636496 & + & - & + & + \\
\hline & KBW 132 & 1996 & India & OL636497 & + & - & + & + \\
\hline T. brevifaciens & TBY 001 & 1995 & USA & OL653669 b & - & - & - & - \\
\hline \multirow{2}{*}{ T. bromi } & ТВН 003 & 1990 & USA & OL653673 ${ }^{b}$ & - & - & - & - \\
\hline & TBH 004 & 1990 & USA & OL653671 b & - & - & - & - \\
\hline T. caries & TCT 030 & 2006 & USA & OL636486 & - & - & - & - \\
\hline T. controversa & TCK 010 & 1990 & USA & OL653668 b & - & - & - & - \\
\hline \multirow{3}{*}{ T. horrida } & THT 003 & 1990 & USA & None $^{c}$ & - & - & - & - \\
\hline & THT 007 & 1993 & Philippines & OL653672 b,c & - & - & - & - \\
\hline & THT 009 & 1995 & USA & None $^{c}$ & - & - & - & - \\
\hline T. laevis & TLT 012 & 1990 & USA & OL636487 & - & - & - & - \\
\hline T. pallida & TPF 001 & 1995 & USA & OL653670 b,d & - & - & - & - \\
\hline
\end{tabular}

Identifications and success of all DNA extractions were confirmed by ITS sequencing using primers ITS5 and ITS4 [61] or ITS5 and LR5 or LR6 [62] for a longer fragment, which includes a portion of the $28 \mathrm{~S}$ region. Methods for PCR and Sanger sequencing were as described in Malloch et al. [63] for DNA from pure cultures. For some of the dried environmental specimens, sequencing with these primer combinations failed, so Tilletia-specific primers MK56-F and Tilletia-R [44]—-targeting the ITS1 only—were used, 
with similar PCR and sequencing protocols except for the following modifications. Bovine Serum Albumin $(20 \mathrm{mg} / \mathrm{mL})$ (ThermoFisher Scientific) was added to the master mix, with a corresponding reduction of $\mathrm{H}_{2} \mathrm{O}$, to enhance PCR success and 45 cycles run instead of 40. Sequences were edited using Geneious Prime 2021.2.2 (https:/ / www.geneious.com, accessed on 8 November 2021).

\subsection{Species-Specific TaqMan qPCR Assay Validation for T. indica and T. walkeri}

Using a comparative genomics approach combined with bioinformatics analyses to identify single-copy orthologous genes unique to the species targeted, Nguyen et al. [43] developed in silico designed qPCR primers and probes for specific detection of four Tilletia species, but no wet-laboratory testing was performed. In this study, preliminary testing using small test sets of reference DNA extracts determined that the one assay targeting T. indica (OG09272) and one of the three assays targeting T. walkeri (OG10415) from that study warranted further validation (Table 4). Both of these species-specific qPCR assays were optimized and tested at the CFIA Ottawa Laboratory Fallowfield (CFIA-OLF) against the complete set of reference target and non-target strains or specimens (Tables 2 and 3; Supplementary Table S1).

Table 4. Tilletia qPCR assay primers and probes, annealing temperatures and limit of detection.

\begin{tabular}{|c|c|c|c|c|}
\hline Target/Assay Name & Primer/Probe Name & Direction/Probe & Sequence $5^{\prime} \rightarrow 3^{\prime}$ a & Annealing Temperature $\left({ }^{\circ} \mathrm{C}\right)$ \\
\hline \multirow{3}{*}{$\begin{array}{c}\text { Tilletia indica/ } \\
\text { TinOG09272 } \\
\text { (Nguyen et al. [43]) }\end{array}$} & OG09272.Tin.F1 & Forward & GAGGACCTTCAAGATCTGACAGG & \multirow{3}{*}{56} \\
\hline & OG09272.Tin.R1 & Reverse & CTGATGATCTTGCCCGGTTTTAC & \\
\hline & OG09272.Tin.P1 & Probe & $\begin{array}{c}\text { 56-FAM/ACACCTAGG/ZEN/ } \\
\text { CСАСТСССТАТCCAGCCA/3IABkFO }\end{array}$ & \\
\hline \multirow{3}{*}{$\begin{array}{c}\text { T. walkeri/ } \\
\text { TwaOG10415 } \\
\text { (Nguyen et al. [43]) }\end{array}$} & OG10415.Twa.F1 & Forward & TCAАСТАСТTCGАСТССТССТСС & \multirow{3}{*}{56} \\
\hline & OG10415.Twa.R1 & Reverse & GCGACACCATCCTTAGTTGTGTA & \\
\hline & OG10415.Twa.P1 & Probe & $\begin{array}{c}\text { 56-FAM/CTTCCGTGA/ZEN/ } \\
\text { TCCCGTCAACGTCGGACT/3IABkFQ }\end{array}$ & \\
\hline \multirow{3}{*}{$\begin{array}{l}\text { T. indica \& T. walkeri } \\
\text { complex/OG01193 } \\
\text { (this study) }\end{array}$} & OG01193.Tin.Twa.F2 & Forward & CAAAGGTCAGCTGCGAGGC & \multirow{3}{*}{68} \\
\hline & OG01193.Tin.Twa.R2 & Reverse & TTCGCCTTTCCTTCCCTTAAGAG & \\
\hline & OG01193.Tin.Twa.P2 & Probe & $\begin{array}{c}\text { 56-FAM/ATTACGGCG/ZEN/ } \\
\text { ACGTACAGCTTCTACCGACTTA/3IABkFQ }\end{array}$ & \\
\hline \multirow{3}{*}{$\begin{array}{l}\text { T. indica \& T. walkeri } \\
\text { complex/OG08220 } \\
\text { (this study) }\end{array}$} & OG08220.Tin.Twa.F1 & $\begin{array}{l}\text { Forward } \\
\text { Reverse }\end{array}$ & ACTGTGACCCTAAACGGTGTGA & \multirow{3}{*}{60} \\
\hline & OG08220.Tin.Twa.P2 & Probe & $\begin{array}{l}\text { TGCTCTGGAGGAGCCGGA } \\
\text { 56-FAM/TCCGCTCAA/ZEN/ }\end{array}$ & \\
\hline & & & ATCAACAACTCGGGTAACCCGGT/3IA & \\
\hline
\end{tabular}

a Obtained from IDT (Integrated DNA Technologies, Coralville, IA, USA; https: / www.idtdna.com, accessed on 8 November 2021).

\subsection{Complex-Specific TaqMan qPCR Assay Design}

Following the orthologous genes approach used by Nguyen et al. [43], searches were performed to identify additional gene regions suitable for development of assays that are (1) specific to the complex of both target species-which form a monophyletic clade within the genus [43,60,64] — and (2) diagnostic against the other species known to occur on wheat. The 10 genome assemblies and annotations published by Nguyen et al. [43] for strains of T. indica (x3), T. walkeri (x2), T. caries ( $\mathrm{x} 1)$, T. controversa ( $\mathrm{x} 2)$, and T. laevis $(\mathrm{x} 2)$ were retrieved from the NCBI database (Table 5).

The orthologous groups defined and the phylogenomics analyses performed in that study using OrthoFinder v1.1.8 [65] were obtained from the authors. New searches identified a candidate single-copy gene common to all five species but distinct for the two targets as compared to the other species (OG01193). Then, using Geneious Prime (2020.0.5) (https: / / www.geneious.com, accessed on 8 November 2021) and the target genome assemblies, a sequence comparison approach consisting of visual screening for regions of interest (i.e., with suitable length and variability for the primers and probe) was used to identify a second candidate gene that was common only to both target species (OG08220). Primers and TaqMan probes were designed for each new gene region (Table 4). 
Table 5. Reference genomes used to design qPCR assays. Table adapted from Nguyen et al. [43].

\begin{tabular}{cccc}
\hline Tilletia Species & Voucher $^{\text {a }}$ & NCBI BioBroject & NCBI SRA \\
\hline caries & DAOMC 238032 & PRJNA317434 & SRR3337315 and SRR3337316 \\
controversa & DAOMC 234426 & PRJNA317433 & SRR3337317, SRR3337319, SRR3337313, SRR6305999, \\
controversa & DAOMC 238052 & PRJNA393324 & SRR6306000, SRR6305997 and SRR6305998 \\
indica & DAOMC 236408 & PRJNA393304 & SRR6305452 \\
indica & DAOMC 236414 & PRJNA393317 & SRR6305448 \\
indica & DAOMC 236416 & PRJNA314779 & SRR3286921, SRR3286931 and SRR3289824 \\
laevis & ATCC 42080 & PRJNA393337 & SRR6305450 \\
laevis & DAOMC 238040 & PRJNA393335 & SRR6305451 \\
walkeri & DAOMC 236422 & PRJNA314785 & SRR3286971 and SRR3289831 \\
walkeri & DAOMC 238049 & PRJNA393320 & SRR6305426 and SRR6305427
\end{tabular}

a DAOMC: Canadian Collection of Fungal Cultures, Ottawa, ON, Canada; ATCC: American Type Culture Collection, Manassas, VA, USA.

\subsection{End-Point PCR Primer Testing}

The species-specific qPCR assays named here as TwaOG10415 and TinOG09272 were tested at $60^{\circ} \mathrm{C}, 58^{\circ} \mathrm{C}$, and $56^{\circ} \mathrm{C}$ based on the primers' annealing temperature recommended in Nguyen et al. [43] and then optimized parameters were selected accordingly. The Eco Master Mix (ThermoFisher Scientific; Cat\# A41141, custom order, on request) was used. Similarly, the primers designed for the complex-specific assays (i.e., OG01193 and OG08220) were challenged and optimized prior to performing real-time PCR tests. The optimum primer annealing temperatures were determined by PCR using temperature gradients of $52-60{ }^{\circ} \mathrm{C}$ and then $61-70{ }^{\circ} \mathrm{C}$, where increments were automatically determined by the Eppendorf Mastercyler pro S instrument (Eppendorf, Hambourg, Germany). The Titanium Taq DNA polymerase (Takara Bio Inc., Nojihigashi, Kusatsu-shi, Shiga, Japan) was used for the initial tests to maximize the amplification success considering that this enzyme can be more permissive than others due to its high robustness conferring high-yield PCR [66]. Given an observed failure of amplification at the higher range of potentially optimal temperatures using the Eco Master Mix (data not shown), all additional tests were run using the QuantiTect Probe PCR Kit (QIAGEN, Hilden, Germany). Details on the PCR reactions volumes, parameters, master mixes tested, and electrophoreses can be found in Appendix A.

\subsection{Real-Time PCR Specificity and Detection Limit}

The assessment of specificity for all four candidate assays was performed in three steps: (1) initially against small test sets of target strains and the non-target species T. controversa DAOMC 236426, followed by (2) testing against the complete set of DNA samples, including T. indica (x31), T. walkeri (x3) and (3) all other reference strains, environmental specimens, and a diverse set of non-Tilletia non-targets (Tables 2 and 3, Supplementary Table S1). All samples and negative water controls were run in triplicate for all four assays. DNA extracts were quantified using a Qubit 2.0 fluorometer (ThermoFisher Scientific) and normalized prior to final qPCR validation testing. Both complex-level assays (i.e., OG01193 and OG08220) were tested at the AAFC Ottawa Research and Development Center (AAFCORDC) and consisted of a $10 \mu \mathrm{L}$ reaction of $0.4 \mu \mathrm{M}$ of each forward and reverse primer, $0.1 \mu \mathrm{M}$ of the TaqMan probe, and one unit of $2 \times$ QuantiTect Probe PCR Kit. The 2-step cycling conditions, run on a LightCycler 480 Instrument II (Roche, Basel, Switzerland), were $15 \mathrm{~min}$ at $95{ }^{\circ} \mathrm{C}$ followed by 50 cycles of $15 \mathrm{~s}$ at $95^{\circ} \mathrm{C}$ and $1 \mathrm{~min}$ at $68^{\circ} \mathrm{C}$ (OG01193) or $60^{\circ} \mathrm{C}$ (OG08220). Both 3-step species-level assays (i.e., TwaOG10415 and TinOG09272), tested at the CFIA-OLF, consisted of a $25 \mu \mathrm{L}$ reaction of $0.48 \mu \mathrm{M}$ of each forward and reverse primer, $0.025 \mu \mathrm{M}$ of TaqMan probe, and one unit of $2 \times$ TaqMan Eco Master Mix. The cycling conditions, run on a ViiA 7 Real-Time PCR System (ThermoFisher Scientific), were $5 \mathrm{~min}$ at $95^{\circ} \mathrm{C}$ followed by 50 cycles consisting of $15 \mathrm{~s}$ at $95^{\circ} \mathrm{C}, 30 \mathrm{~s}$ at $56^{\circ} \mathrm{C}$ and $72{ }^{\circ} \mathrm{C}$ for $30 \mathrm{~s}$. 
The limit of detection (LOD) for each assay was assessed with reference DNA for the target species, T. indica DAOM 236416 and T. walkeri DAOMC 236422 using six serial dilutions (1:10) of DNA normalized to approximately $2 \mathrm{ng} / \mathrm{uL}$ (i.e., 2.2 to $2.2 \times 10^{-6} \mathrm{ng} / \mu \mathrm{L}$ ). Standard curves for the two species-specific assays were assessed at CFIA-OLF and AAFCORDC, on two different instruments. Those for the complex assays, for both target species, were completed at AAFC-ORDC only. To robustly evaluate the LOD, 15 additional replicates for three of the lowest concentrations (i.e., $2.2 \times 10^{-3}$ to $2.2 \times 10^{-5} \mathrm{ng} / \mu \mathrm{L}$ ) were tested for each assay.

Challenging assay specificity was done by running each one against DNA from 35 strains or environmental specimens representing 10 non-target Tilletia species, namely T. asperifolia, T. brevifaciens, T. bromi (= T. bromi-tectorum), T. caries, T. controversa, T. fusca, T. goloskokovii, T. horrida, T. laevis, and T. pallida (Tables 2 and 3). In addition, the four assays were tested against DNA from an uninfected wheat host plant and from 25 strains or herbarium specimens representing 19 non-Tilletia wheat and/or grain-crop pathogens causing rusts (Puccinia spp.), smuts (Ustilago nuda and Urocystis tritici), molds (Cladosporium spp., Aspergillus foetidus and Penicillium verrucosum), spots and blights (Didymella glomerata, Pyrenophora tritici-repentis, Septoria glycines and Fusarium graminearum), blotches (Parastagonospora nodorum and Bipolaris sorokiniana), powdery mildew (Blumeria graminis), and black point and smudge (Alternaria alternata) (Supplementary Table S1).

\subsection{Test Validation of The IPPC Sanctioned ITS1 qPCR Assay}

Using the same reference DNA extracts and serial dilutions as were used to generate standard curves in Section 2.5, the qPCR assays published by Tan et al. [49] for T. indica, T. walkeri, and T. horrida were tested at AAFC-ORDC individually and also as a three-plex assay, as validated by Valente et al. [50], following the same protocol. The qPCR reaction mix components and cycling conditions were not changed from the original reference. For these tests, the reference DNA was normalized to $\sim 1 \mathrm{ng} / \mu \mathrm{L}$ before making 10 -fold serial dilutions.

\section{Results}

\subsection{Fungal Material and DNA Extraction}

An ITS DNA barcode sequence was generated for each of the reference fungal cultures or specimens in this study, using DNA concentrations normalized at $1 \mathrm{ng} / \mu \mathrm{L}$, and deposited in GenBank (Tables 2 and 3; Supplementary Table S1). For most, the complete ITS sequence was determined. For some of the field-collected environmental specimens, the use of group-specific primers that amplify the ITS1 region only were required to avoid amplification of the host or contaminants. Identifications were verified by sequence alignments (BLAST searches) on NCBI and by DNA sequence analyses using Geneious (data not shown).

\subsection{Species-Specific and Complex-Specific qPCR Assay Design}

The primers and probes for the two assays designed by Nguyen et al. [43] and the two complex assays designed in this study are listed in Table 4. Sequence alignments of T. walkeri and T. indica showing the gene regions used to design qPCR assays OG08220 and OG01193, and the primer and probe locations, are presented in Supplementary Data S1.

\subsection{End-Point PCR Primer Testing}

For the species-specific assays TwaOG10415 and TinOG09272, primer testing at temperatures over $56^{\circ} \mathrm{C}$ and using 2-step reactions revealed critical problems that translated into large DNA smears when visualised on the Qiaxcel instrument (data not shown). The results from the optimized 3-step reactions (i.e., extension step added, and decreased annealing time) at $56{ }^{\circ} \mathrm{C}$ displayed a single clear band on gel. Results from the temperature gradient testing for the primers of the two complex-specific qPCR assays OG01193 and OG08220 were used to determine the annealing temperature to be subsequently used for 
qPCR. Using the QuantiTect Probe PCR mix, OG01193 showed single target-sized bands $(\approx 150 \mathrm{bp})$ at $68.5^{\circ} \mathrm{C}$ on gel, whereas OG08220 displayed similar results over a broader temperature range of $58.5-68.5^{\circ} \mathrm{C}$. Based on the additional qPCR tests (data not shown), the respective annealing temperatures picked for downstream qPCR proceeding were $68^{\circ} \mathrm{C}$ and $60^{\circ} \mathrm{C}$.

\subsection{Real-Time PCR Specificity and Detection Limit}

Testing against the complete panel of DNA extracts (Tables 2 and 3; Supplementary Table S1) confirmed the specificity of the four new qPCR assays. All T. indica and T. walkeri reference strains and environmental specimens were positively detected and all non-target Tilletia species, other fungi, and the wheat host were negative. For all four assays and for both target species, the standard curves amplified consistently up to the fourth dilution, i.e., $\sim 2.2 \times 10^{-4} \mathrm{ng} / \mu \mathrm{L}$ (Figure 1), indicating an LOD of $0.22 \mathrm{pg}(=220 \mathrm{fg}$ ). Results at CFIA-OLF for the species-specific assays (data not shown) were consistent with results at AAFC-ORDC. The actual LOD was determined to be between $0.22 \mathrm{pg}$ and $0.02 \mathrm{pg}$ because some replicates also amplified at the $10^{-5}$ dilution: $22 \%$ for both species-specific assays, $17 \%$ for OG08220 and 39\% for OG01193 with T. indica, and 44\% for OG08220 and 33\% for OG01193 with T. walkeri. Amplification efficiencies for each assay with each target are shown on Figure 1.
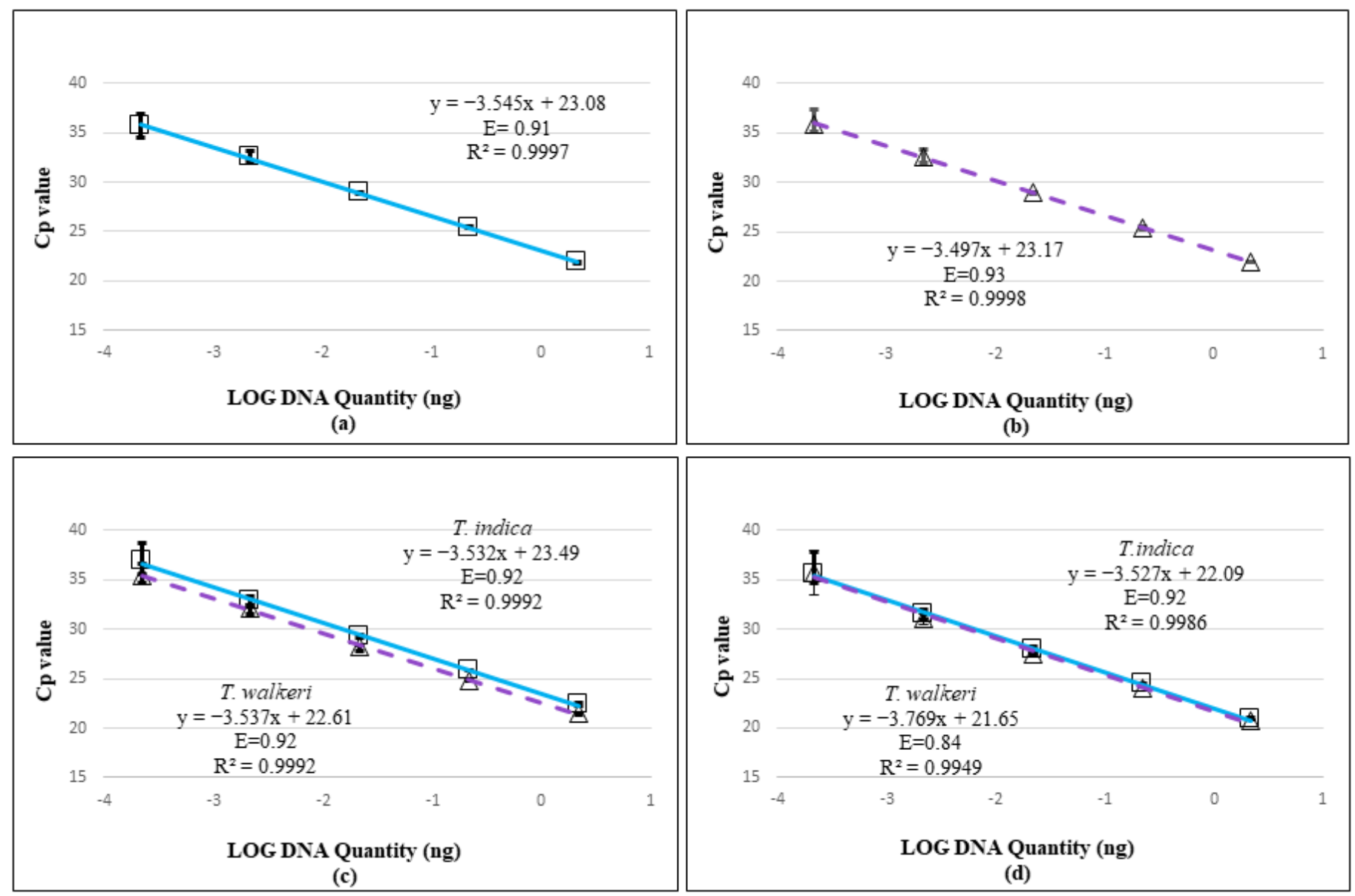

Figure 1. Standard curves showing the regression between DNA log quantities (ng, $\mathrm{x}$-axis) and cycle thresholds (Cp, y-axis) for the four qPCR assays, generated with serial dilutions $\left(\sim 2.2\right.$ to $\left.\sim 2.2 \times 10^{-4} \mathrm{ng} / \mu \mathrm{L}\right)$ of the target species, T. indica DAOMC 236416 (squares/solid line) and T. walkeri DAOMC 236422 (triangles/dotted line). (a) TinOG09272 specific to T. indica; (b) TwaOG10415 specific to T. walkeri; and complex-specific detecting both species, (c) OG08220 and (d) OG01193. Plotted are the average $\mathrm{Cp}$ values for the initial 3 replicates run for each dilution and error bars for all replicates ( 3 for the first three dilutions, 18 for the last 2). 


\subsection{Test Validation of The IPPC Sanctioned ITS1 qPCR Assay}

Three of the assays included in the Tan et al. [49] 5-plex set of ITS assays were validated on our LightCycler 480 instrument using our reference DNA samples and they performed as expected. Our standard curve tests confirmed LODs close to $0.1 \mathrm{pg}$ for both the T. indica and T. walkeri assays (data not shown). Although cross-reaction of the two species was observed, the amplification curves were different and by using the recommended allelic discrimination step at the end of each run, both species were successfully differentiated. The T. horrida assay confirmed identifications of three sampled environmental specimens (Table 3) and was negative for both T. indica and T. walkeri.

\section{Discussion}

The qPCR assays validated in this study were developed for single-copy genomic DNA regions of the target species and to provide new tools to identify and discriminate the closely-related phytopathogens T. indica and T. walkeri. The former species is of high concern and is subject to regulations related to imports and exports of wheat and grain shipments. The latter, a ryegrass pathogen, presents challenges for accurate differentiation from T. indica because of similarities in teliospore morphology and limited ITS sequence differences, a multi-copy gene region commonly used for fungal identifications and as a basis for DNA-based assay development.

The experimental LOD obtained is similar across all four assays, approximately $200 \mathrm{fg}$, which is highly sensitive for single copy genes and more sensitive than several published molecular assays targeting mitochondrial DNA (= multi-copy) such as those by Tan et al. [16], Frederick et al. [37], and Gao et al. [55]. By comparison, Bilodeau et al. [67] obtained a detection of $3 \mathrm{fg}$ for a qPCR assay targeting the Intergenic region in Verticillium species, which was estimated to be $\sim 24$ to 73 copies per haploid genome, with an average of $\sim 46$ copies depending on the isolate. It can be inferred that the estimate for a single copy gene would be between 200 and $75 \mathrm{fg}$, similar to the actual LOD for each assay in this study, which is between 200 and $20 \mathrm{fg}$. This compares favourably with published ITS qPCR assays, such as those with TaqMan probes published by Tan et al. [49] and recommended by the IPPC [52], reported to be $0.1 \mathrm{pg}$ (=100 fg). Gurjar et al. [51] published an ITS qPCR SYBR Green assay with an LOD of $0.1 \mathrm{pg}$, but it was not validated against samples of T. walkeri. Assays based on ITS have the advantage of targeting a multi-copy gene, hence the lower LODs, but their specificity is based on a single SNP either in the ITS1 [49] or ITS2 [51] — non-coding regions subject to mutation — and depends on discrimination at the allelic level for accurate diagnostics of T. indica and T. walkeri.

Besides the comprehensive testing using reference DNA for multiple Tilletia species, our assays were also challenged with DNA from environmental specimens and a broad range of non-target fungi that also occur on wheat, demonstrating robustness. Testing was completed in two different laboratories using different instruments for the species-specific versus complex assays, while the standard curve validations were all completed by the same laboratory and machine, demonstrating transferability. The level of resolution achieved is, in part, attributable to the genome-wide in silico approach that revealed the unknown genomic regions used here, instead of the insufficiently variable ITS. Nguyen et al. [43] reported a pronounced difference in estimated genome size between the two target speciesapproximately $30 \mathrm{Mb}$ for $T$. indica and about $24 \mathrm{Mb}$ for T. walkeri-which facilitated the discovery of the unique regions targeted for three of our four assays. By contrast, the OG01193 locus is common to all four species sequenced by Nguyen et al. [43] but has marked sequence variation between the targets' complex and the T. caries/T. controversa/ T. laevis complex (Supplementary Data S1).

\section{Conclusions}

The new assays presented here offer an efficient, high-throughput and directly usable tool for the detection of Karnal bunt and ryegrass bunt from infected material, while allowing diagnostic labs to reduce their reliance on time- and resource-consuming pre- 
treatments and analyses such as microscopy, single-spore isolation, teliospore germination and pure culture isolations. Complex and species-specific identification is possible using three of them. The assay pairs provide a hierarchical approach to diagnostics, whereby either of the two that target the species complex (i.e., OG08820 and OG01193), or both for more robust confirmation, can be used as a preliminary test to assess the presence/absence of either species. If positive results occur, additional testing can follow using the two assays that target unique genomic regions (i.e., TinOG09272 and TwaOG10415) for speciesspecific detection. This approach can be used in combination with spore identification and quantification using microscopy of grain or seed wash samples, providing additional evidence for regulatory decision-making and increasing sample processing throughput.

While there is more work to be done to enhance the discrimination of other highly unwanted species such as Tilletia controversa, the causal agent of dwarf bunt, the combination of bioinformatics, and molecular biology technologies used here certainly should be considered as a faster way of screening for key regions within genomes. Tilletia controversa is, like T. indica, another pathogen that has several closely-related species (including the common bunt species T. caries and T. laevis) that are generally less concerning for wheat production and international trade, hence the importance of achieving high resolution and sensitivity for diagnostics.

Supplementary Materials: The following are available online at https:/ / www.mdpi.com/article/1 0.3390/biology10121295/s1, Supplementary Table S1: Non-Tilletia wheat or grass pathogens and wheat (host plant) against which the qPCR assays were tested. Supplementary Data S1: A. Sequence alignment of the genic region OG08220 for Tilletia walkeri and T. indica isolates sequenced by Nguyen et al. [43]; B. Sequence alignment of the isolates sequenced by Nguyen et al. [43] presenting part of the region OG01193 unique to Tilletia walkeri and T. indica used for the qPCR assay design. References [68-70] are cited in the supplementary materials.

Author Contributions: Conceptualization: É.D.T. and S.H.; formal analysis: É.D.T. and S.H.; funding acquisition: G.J.B. and S.H.; investigation: É.D.T., J.C. and S.H.; methodology: É.D.T., G.J.B. and S.H.; resources S.H. and G.J.B.; supervision: É.D.T., G.J.B. and S.H.; validation: É.D.T., J.C. and S.H.; visualization: É.D.T. and S.H.; writing—original draft: É.D.T. and S.H.; writing-review and editing: É.D.T., J.C., G.J.B. and S.H. All authors have read and agreed to the published version of the manuscript.

Funding: This research was funded by Agriculture and Agri-Food Canada grant number J-002272 "Fungal and Bacterial Biosystematics" with additional support from the Canadian Food Inspection Agency, N-000277 "Advanced pre-screening of export grain and oilseed commodities using machine learning on long read sequencing"; and N-000095 "Identification of molecular markers for development of detection and genotyping tools for regulated plant pathogens".

Institutional Review Board Statement: Not applicable.

Informed Consent Statement: Not applicable.

Data Availability Statement: Reference ITS sequences for the voucher material used in this study are deposited in GenBank (Tables 2 and 3, and Supplementary Table S1: OL636509-OL636519 and OL712411-OL712415).

Acknowledgments: The authors would like to thank Gary Peterson and Doug Luster at the United States Department of Agriculture, Agriculture Research Service, for providing the environmental specimens listed in Table 3, Hai Nguyen (AAFC-ORDC) for sharing genomic data, and Debbie Shearlaw (CFIA-OLF) for helping with validation tests and reviewing this article.

Conflicts of Interest: The authors declare no conflict of interest.

\section{Appendix A. PCR Protocols for Temperature Optimization}

For assays TinOG09272 and TwaOG10415, the $25 \mu \mathrm{L}$ reaction comprised $0.48 \mu \mathrm{M}$ of each forward and reverse respective primer (Table 4), and one unit of $2 \times$ TaqMan Eco Master Mix. The 3-step cycling conditions, run on a ViiA 7 Real-Time PCR System, were $5 \mathrm{~min}$ at $95^{\circ} \mathrm{C}$ followed by 50 cycles consisting of $15 \mathrm{~s}$ at $95^{\circ} \mathrm{C}, 30 \mathrm{~s}$ at $56^{\circ} \mathrm{C}$ and $72{ }^{\circ} \mathrm{C}$ for 
$30 \mathrm{~s}$. PCR products were evaluated on a Qiaxcel Advanced instrument (QIAGEN) using a QIAxcel DNA High Resolution Kit (1200) (QIAGEN) and following the user's manual for the OM500 method.

For assays OG01193 and OG08220, the PCR reactions prepared were similar to those described in Malloch et al. [63] (see Section 2.1) and run on an Eppendorf Mastercycler pro S. The $10 \mu \mathrm{L}$ reactions comprised $0.08 \mu \mathrm{M}$ of each forward and reverse primer, $0.5 \times$ Titanium Taq DNA polymerase (Takara), $1 \times$ Titanium Taq buffer (Takara), $0.1 \mathrm{mM}$ dNTPs, $1 \mu \mathrm{L}$ of stock DNA and PCR-grade water for the remaining volume. Cycling conditions were $3 \mathrm{~min}$ at $95^{\circ} \mathrm{C} ; 45$ cycles for $1 \mathrm{~min}$ at $95^{\circ} \mathrm{C}, 1 \mathrm{~min} 30 \mathrm{~s}$ at 52, 54.6, 56, $58.5,60,62$, and $64.6^{\circ} \mathrm{C}$ for OG01193, and $52,54.6,56$, and $58.5^{\circ} \mathrm{C}$ for OG08220, and 2 min at $72{ }^{\circ} \mathrm{C}$ for each cycle; and $8 \mathrm{~min}$ at $72{ }^{\circ} \mathrm{C}$.

Once amplification was confirmed at lower temperatures with the Titanium Taq polymerase, testing was pursued using the QuantiTect Probe PCR Kit at higher temperatures. The $10 \mu \mathrm{L}$ QuantiTect reactions comprised $1 \times$ QuantiTect Probe PCR master mix, $0.4 \mu \mathrm{M}$ of each forward and reverse primer, $1 \mu \mathrm{L}$ of stock DNA and PCR-grade water for the remaining volume. The reactions were performed as follows: $10 \mathrm{~min}$ at $95^{\circ} \mathrm{C} ; 50$ cycles for $15 \mathrm{~min}$ at $95^{\circ} \mathrm{C}$ and $30 \mathrm{~s}$ at $62,64.6,66$, and $68.5^{\circ} \mathrm{C}$ for OG01193, and 58.5, 60, 62, 64.6, 66 , and $68.5^{\circ} \mathrm{C}$ for OG08220 for each cycle; and $30 \mathrm{~s}$ at $40^{\circ} \mathrm{C}$. PCR products were loaded on a $1.5 \%$ agarose gel, and visualized on a Gel Doc XR+ instrument (Bio-Rad, Hercules, California, CA, USA) (data not shown).

\section{References}

1. Mitra, M. A new bunt on wheat in India. Ann. Appl. Biol. 1931, 18, 178-179. [CrossRef]

2. Sansford, C.; Baker, R.; Brennan, J.; Ewert, F.; Gioli, B.; Inman, A.; Kinsella, A.; Magnus, H.; Miglietta, F.; Murray, G. The new Pest Risk Analysis for Tilletia indica, the cause of Karnal bunt of wheat, continues to support the quarantine status of the pathogen in Europe. Plant Pathol. 2008, 57, 603-611. [CrossRef]

3. Fuentes-Davila, G.; Rajaram, S.; Van-Ginkel, M.; Rodriguez-Ramos, R.; Abdalla, O.; Mujeeb-Kazi, A. Artificial Screening for Resistance to Tilletia indica. Cereal Res. Commun. 1996, 24, 469-475.

4. CABI. Invasive Species Compendium-Tilletia indica (Karnal Bunt of Wheat). Available online: https://www.cabi.org/isc/datashe et/36168 (accessed on 25 March 2020).

5. EPPO. Tilletia indica (NEOVIN). Available online: https://gd.eppo.int/taxon/NEOVIN (accessed on 25 March 2020).

6. Singh, D.; Agarwal, R.; Shrestha, J.; Thapa, B. First report of Tilletia indica on wheat in Nepal. Plant Dis. 1989, 73, 273. [CrossRef]

7. Munjal, R. Status of Karnal bunt (Neovossia indica) of wheat in Northern India during 1968-69 and 1969-70. Indian J. Mycol. Plant Pathol. 1975, 5, 185-187.

8. Crous, P.; Van Jaarsveld, A.; Castlebury, L.; Carris, L.; Frederick, R.; Pretorius, Z. Karnal bunt of wheat newly reported from the African continent. Plant Dis. 2001, 85, 561. [CrossRef]

9. Duran, R. Aspects of teliospore germination in North American smut fungi. II. Can. J. Bot. 1972, 50, 2569-2574. [CrossRef]

10. Bonde, M.; Peterson, G.; Schaad, N.; Smilanick, J. Karnal bunt of wheat. Plant Dis. 1997, 81, 1370-1377. [CrossRef] [PubMed]

11. Da Luz, W.; Mendes, M.; Ferreira, M.; Urben, A. Tilletia indica on wheat in the south of the state of Rio Grande do Sul, Brazil and measures for eradication. Fitopatol. Bras. 1993, 18, 1370-1377.

12. Ykema, R.; Floyd, J.; Palm, M.; Peterson, G. First report of Karnal bunt of wheat in the United States. Plant Dis. 1996, 80, 1207. [CrossRef]

13. Beattie, B.; Biggerstaff, D. Karnal Bunt: A Wimp of a Disease... But an Irresistible Political Opportunity. Choices 1999, 14, 4-8.

14. Rush, C.; Stein, J.; Bowden, R.; Riemenschneider, R.; Boratynski, T.; Royer, M. Status of Karnal bunt of wheat in the United States 1996 to 2004. Plant Dis. 2005, 89, 212-223. [CrossRef] [PubMed]

15. Agarwal, V.; Singh, D.; Mathur, S. Karnal bunt. In Seed-Borne Diseases and Seed Health Testing of Wheat; Mathur, S., Cunfer, B., Eds.; Danish Government Institute of Seed Pathology for Developing Countries: Copenhagen, Denmark, 1993; pp. 31-43.

16. Tan, M.; Raman, H.; Chambers, G.; Sharma, I.; Chen, Z.; Deshpande, N.; Wilkins, M. Characterization of SNP and structural variations in the mitochondrial genomes of Tilletia indica and its closely related species formed basis for a simple diagnostic assay. PLoS ONE 2016, 11, e0166086. [CrossRef] [PubMed]

17. Mitra, M. Stinking smut (bunt) of wheat with special reference to Tilletia indica. Indian J. Agric. Sci. 1935, 5, 51-74.

18. Fuentes-Davila, G. Karnal bunt. In Bunt and Smut Diseases of Wheat: Concepts and Methods of Disease Management; Wilcoxson, R.D., Saari, E.E., Eds.; CIMMYT: Mexico City, Mexico, 1996; pp. 26-32.

19. Duran, R.; Fischer, G. The Genus Tilletia; Washington State University: Washington, DC, USA, 1961.

20. Holton, C. Observations on Neovossia indica. Indian Phytopathol. 1949, 2, 1-5.

21. Tillet, M. Dissertation on the Cause of the Corruption and Smutting of the Kernels of Wheat in the Head and the Means of Preventing These Untoward Circumstances; The American Phytopathological Society: St. Paul, MN, USA, 1755; Volume 5, pp. 1-150. 
22. Palm, M. Mycology and world trade: A view from the front line. Mycologia 1999, 91, 1-12. [CrossRef]

23. Castlebury, L.; Carris, L. Tilletia walkeri, a new species on Lolium multiflorum and L. perenne. Mycol. Balc. 1999, 91, 121-131. [CrossRef]

24. Vocke, G.; Allen, E.; Price, J. Economic analysis of ending the issuance of Karnal Bunt phytosanitary wheat export certificates. In Wheat Yearbook; United States Department of Agriculture Economic Research Service: Washington, DC, USA, 2002.

25. White, E. Canada bans U.S. durum until karnal bunt under control. The Western Producer, 4 April 1996.

26. United States Department of Agriculture. Karnal Bunt. Available online: https://www.aphis.usda.gov/aphis/ourfocus/planth ealth/plant-pest-and-disease-programs/pests-and-diseases/karnal-bunt/ct_karnal_bunt (accessed on 13 July 2020).

27. Nielsen, B.J.; Borgen, A.; Nielsen, G.C.; Scheel, C. Strategies for controlling seed-borne diseases in cereals and possibilities for reducing fungicide seed treatments. In Proceedings of the Brighton Crop Protection Conference: Pests and Diseases, Brighton, UK, 16-19 November 1998; pp. 893-900.

28. Borgen, A. Hvedens Stinkbrand-en Udfordring Forprincipperne for Økologisk Plantebeskyttelse (Common Bunt of Wheata Challenge to the Principles of Ecological Plant Protection). Ph.D. Thesis, Royal Veterinary and Agricultural University, Frederiksberg, Denmark, 2000.

29. Borgen, A.; Davanlou, M. Biological control of common bunt (Tilletia tritici) in organic farming. J. Plant Prod. 2000, 3, 159-174.

30. Oerke, E. Crop losses to pests. J. Agric. Sci. 2006, 144, 31-43. [CrossRef]

31. Turgay, E.; Oğuz, A.; Ölmez, F. Chapter 15-Karnal bunt (Tilletia indica) in wheat. In Climate Change and Food Security with Emphasis on Wheat; Ozturk, M., Gul, A., Eds.; Academic Press: Cambridge, MA, USA, 2020; pp. 229-241. [CrossRef]

32. West, J.; Townsend, J.; Stevens, M.; Fitt, B. Comparative biology of different plant pathogens to estimate effects of climate change on crop diseases in Europe. Eur. J. Plant Pathol. 2012, 133, 315-331. [CrossRef]

33. Baker, R.; Sansford, C.; Jarvis, C.; Cannon, R.; MacLeod, A.; Walters, K. The role of climatic mapping in predicting the potential geographical distribution of non-indigenous pests under current and future climates. Agric. Ecosyst. Environ. DNA 2000, 82, 57-71. [CrossRef]

34. Carris, L.; Castlebury, L.; Goates, B. Nonsystemic bunt fungi-Tilletia indica and T. horrida: A review of history, systematics, and biology. Annu. Rev. Phytopathol. 2006, 44, 113-133. [CrossRef]

35. Workman, D. Wheat Exports by Country. Available online: http://www.worldstopexports.com/wheat-exports-country/ (accessed on 31 March 2020).

36. Farr, D.; Rossman, A. Fungal Databases U.S. National Fungus Collections. Agricultural Research Service United States Department of Agriculture. Available online: https:/ / nt.ars-grin.gov/fungaldatabases / (accessed on 18 October 2021).

37. Frederick, R.; Snyder, K.; Tooley, P.; Berthier-Schaad, Y.; Peterson, G.; Bonde, M.; Schaad, N.; Knorr, D. Identification and differentiation of Tilletia indica and T. walkeri using the polymerase chain reaction. Phytopathology 2000, 90, 951-960. [CrossRef] [PubMed]

38. Canadian Food Inspection Agency. List of Pests Regulated by Canada. Available online: http://www.inspection.gc.ca/plants/pl ant-pests-invasive-species / pests / regulated-pests/eng/1363317115207/1363317187811 (accessed on 20 March 2020).

39. Australian Government-Department of Agriculture Water and the Environment. Plant Pests and Diseases-Karnal Bunt. Available online: https: / / www.agriculture.gov.au/pests-diseases-weeds/plant/karnal-bunt (accessed on 23 March 2020).

40. Farr, D.; Rossman, A. Fungal Databases, U.S. National Fungus Collections. Available online: https://nt.ars-grin.gov / fungaldata bases / (accessed on 13 July 2020).

41. Mathre, D.E. Bunts and smuts revisited: Has the air been cleared? Plant Health Prog. 2000, 1, 1-6. [CrossRef]

42. Levy, L.; Castlebury, L.; Carris, L.; Meyer, R.; Pimentel, G. Internal transcribed spacer sequence-based phylogeny and polymerase chain reaction-restriction fragment length polymorphism differentiation of Tilletia walkeri and T. indica. Phytopathology 2001, 91, 935-940. [CrossRef]

43. Nguyen, H.; Sultana, T.; Kesanakurti, P.; Hambleton, S. Genome sequencing and comparison of five Tilletia species to identify candidate genes for the detection of regulated species infecting wheat. IMA Fungus 2019, 10, 11. [CrossRef] [PubMed]

44. Tan, M.; Murray, G. A molecular protocol using quenched FRET probes for the quarantine surveillance of Tilletia indica, the causal agent of Karnal bunt of wheat. Mycol. Res. 2006, 110, 203-210. [CrossRef] [PubMed]

45. Pimentel, G.; Carris, L.; Levy, L.; Meyer, R. Genetic variability among isolates of Tilletia barclayana, T. indica and allied species. Mycologia 1998, 90, 1017-1027. [CrossRef]

46. Thirumalaisamy, P.; Singh, D.; Aggarwal, R.; Gogoi, R.; Kumar Gupta, P.; Kumar Singh, P. Development of specific primers for detection of Karnal bunt pathogen of wheat. Indian Phytopathol. 2011, 64, 164-172.

47. McDonald, J.; Wong, E.; White, G. Differentiation of Tilletia species by rep-PCR genomic fingerprinting. Plant Dis. 2000, 84, 1121-1125. [CrossRef] [PubMed]

48. Kochanová, M.; Prokinová, E.; Ryšánek, P. Laboratory Diagnostics of Common Bunt and Dwarf Bunt. In Proceedings of the XVth Biennial Workshop on the Smut Fungi, Prague, Czech Republic, 11-14 June 2006; pp. 75-77.

49. Tan, M.; Ghalayini, A.; Sharma, I.; Yi, J.; Shivas, R.; Priest, M.; Wright, D. A one-tube fluorescent assay for the quarantine detection and identification of Tilletia indica and other grass bunts in wheat. Australas. Plant Pathol. 2009, 38, 101-109. [CrossRef]

50. Valente, M.; Bragaloni, M.; Di Giambattista, G.; Riccioni, L. Test validation for the detection of Tilletia indica Mitra by multiplex real-time PCR. EPPO Bull. 2019, 49, 104-110. [CrossRef] 
51. Gurjar, M.; Aggarwal, R.; Jogawat, A.; Sharma, S.; Kulshreshtha, D.; Gupta, A.; Gogoi, R.; Thirumalaisamy, P.; Saini, A. Development of real time PCR assay for detection and quantification of teliospores of Tilletia indica in soil. Indian J. Exp. Biol. 2017, $55,549-554$.

52. IPPC. International Standard for Phytosanitary Measures 27. In Annex 04 DP 04: Tilletia indica Mitra; International Plant Protection Convention (IPPC) and Food and Agriculture Organization of the United Nations (FAO): Rome, Italy, 2016; Volume IPSM, Annex 4, p. 28.

53. Smith, O.; Peterson, G.; Beck, R.; Schaad, N.; Bonde, M. Development of a PCR-based method for identification of Tilletia indica, causal agent of Karnal bunt of wheat. Phytopathology 1996, 86, 115-122. [CrossRef]

54. Ferreira, M.; Tooley, P.; Hatziloukas, E.; Castro, C.; Schaad, N. Isolation of a species-specific mitochondrial DNA sequence for identification of Tilletia indica, the Karnal bunt of wheat fungus. Appl. Environ. Microbiol. 1996, 62, 87-93. [CrossRef]

55. Gao, Y.; Tan, M.; Zhu, Y. Rapid and specific detection of Tilletia indica using loop-mediated isothermal DNA amplification. Australas. Plant Pathol. 2016, 45, 361-367. [CrossRef]

56. Mishra, A.; Singh, U.; Goel, R.; Kumar, A. PCR based molecular technique for identification and discrimination of quarantined and non-quarantined Tilletia sps. Indian J. Exp. Biol. 2002, 40, 1137-1142.

57. Begum, S.; Mathur, S. Karnal bunt and loose smut in wheat seed lots in Pakistan. FAO Plant Prot. Bull. 1989, $37,165-173$.

58. Peterson, G.; Bonde, M.; Phillips, J. Size-selective sieving for detecting teliospores of Tilletia indica in wheat seed samples. Plant Dis. 2000, 84, 999-1007. [CrossRef]

59. Sharma, P.; Sharma, S.; Pandey, B.; Muthusamy, S.; Kumar, S.; Saharan, M.; Kumar, S.; Singroha, G.; Sharma, I.; Singh, G. Development and validation of microsatellite markers for Karnal bunt (Tilletia indica) and loose smut (Ustilago segetum tritici) of wheat from related fungal species. J. Phytopathol. 2018, 166, 729-738. [CrossRef]

60. Castlebury, L.; Carris, L.; Vánky, K. Phylogenetic analysis of Tilletia and allied genera in order Tilletiales (Ustilaginomycetes; Exobasidiomycetidae) based on large subunit nuclear rDNA sequences. Mycologia 2005, 97, 888-900. [CrossRef]

61. White, T.; Bruns, T.; Lee, S.; Taylor, J. Amplification and direct sequencing of fungal ribosomal RNA genes for phylogenetics. In PCR Protocols: A Guide to Methods and Applications; Academic Press: Cambridge, MA, USA, 1990. [CrossRef]

62. Vilgalys, R.; Hester, M. Rapid genetic identification and mapping of enzymatically amplified ribosomal DNA from several Cryptococcus species. J. Bacteriol. 1990, 172, 4238-4246. [CrossRef] [PubMed]

63. Malloch, D.; Sigler, L.; Hambleton, S.; Vanderwolf, K.; Gibas, C.; McAlpine, D. Fungi associated with hibernating bats in New Brunswick caves: The genus Leuconeurospora. Botany 2016, 94, 1171-1181. [CrossRef]

64. Tremblay, É.D.; Shearlaw, D.; Nguyen, H.D.T.; Bilodeau, G.J.; Hambleton, S. Laboratory testing of qPCR assays designed in silico reveal promising results to rapidly identify phytopathogenic Tilletia species. In Proceedings of the Plant Canada 2019 Meeting, Guelph, ON, Canada, 7-10 July 2019.

65. Emms, D.; Kelly, S. OrthoFinder: Solving fundamental biases in whole genome comparisons dramatically improves orthogroup inference accuracy. Genome Biol. 2015, 16, 157. [CrossRef]

66. Takara Bio Inc. High-yield PCR. Available online: https://www.takarabio.com/products/pcr/high-yield-pcr/titanium-taq-pro ducts (accessed on 24 March 2020).

67. Bilodeau, G.; Koike, S.; Uribe, P.; Martin, F. Development of an assay for rapid detection and quantification of Verticillium dahliae in soil. Phytopathology 2012, 102, 331-343. [CrossRef] [PubMed]

68. Liu, M.; Hambleton, S. Taxonomic study of stripe rust, Puccinia striiformis sensu lato, based on molecular and morphological evidence. Fungal Biol. 2010, 114, 881-899. [CrossRef] [PubMed]

69. Chen, W.; Radford, D.R.; Hambleton, S. Towards improved detection and identification of rust fungal pathogens in environmental samples using a metabarcoding approach. Phytopathology 2021. [CrossRef] [PubMed]

70. Liu, M.; Hambleton, S. Puccinia chunjii, a close relative of the cereal stem rusts revealed by molecular phylogeny and morphological study. Mycologia 2012, 104, 1056-1067. [CrossRef] [PubMed] 